\title{
Broad Money Demand and Asset Substitution in China
}

Ge Wu 


\title{
IMF Working Paper
}

Asia and Pacific Department

\section{Broad Money Demand and Asset Substitution in China}

\author{
Prepared by Ge $\mathrm{Wu}^{1}$ \\ Authorized for distribution by Shogo Ishii
}

June 2009

\begin{abstract}

\section{This Working Paper should not be reported as representing the views of the IMF.}

The views expressed in this Working Paper are those of the author(s) and do not necessarily represent those of the IMF or IMF policy. Working Papers describe research in progress by the author(s) and are published to elicit comments and to further debate.

Recent changes to China's financial system, in particular ongoing interest rate liberalization, gradual movement toward a more flexible exchange rate regime, and rapid development of capital markets, have changed substantially the environment in which monetary policy operates. In light of these changes, we estimate an error correction model using a General-to-Specific methodology and confirm that a stable broad money demand function exists taking proper account of asset substitution, with an income elasticity of less than unity. Current inflation is found to have a significant negative impact on the real money demand. However, money demand does not appear very sensitive to interest rates, possibly reflecting their partial liberalization. Changes in the exchange rate also do not affect money demand significantly, but expectations of a further renminbi appreciation since 2005 appears to induce more money demand. Stock prices are statistically insignificant despite recent investors' interest in equity markets.
\end{abstract}

JEL Classification Numbers:C50; E41; O53

Keywords: Money demand, asset substitution, exchange rate, interest rate, China Author’s E-Mail Address:wuge@pbc.gov.cn

\footnotetext{
${ }^{1}$ People's Bank of China. The paper was written while I was a special appointee in the IMF's Asia and Pacific Department. I am grateful to Yi Gang of the People's Bank of China and Neil R. Ericsson of the Federal Reserve Board for their guidance. I also would especially like to thank David Cowen of the IMF for his comments and encouragement, as well as Li Cui, Tao Sun, Zaijin Zhan, Yi Wu, and Man-Keung Tang, also of the IMF, and Zhiwei Zhang of Hong Kong Monetary Authority, for their suggestions.
} 


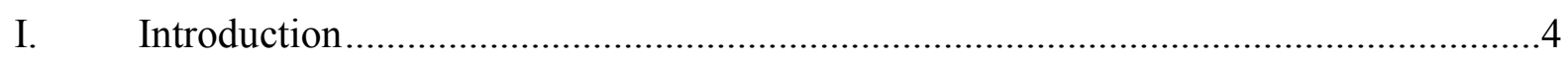

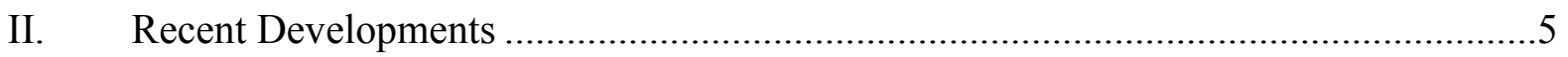

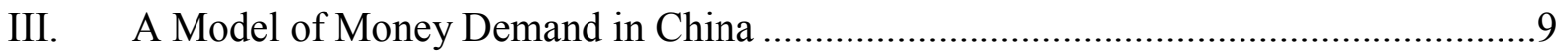

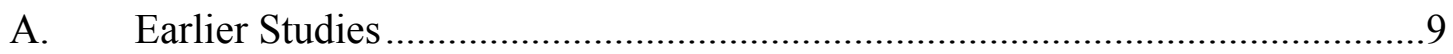

B. Model Specification ................................................................................. 10

C. Integration and Cointegration Tests..............................................................11

D. A Dynamic Model of Money Demand …………..........................................16

E. The Model's Properties..................................................................................

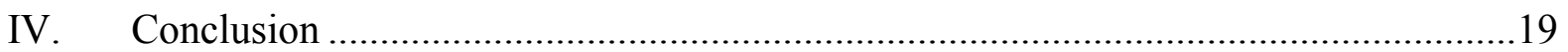

Figures

1. Actual and Targeted M2 Growth Rate, 1999-2007 ...................................................

2. Renminbi Nominal Exchange Rate and REER, 1994-2008 .....................................

3. Currency Substitution and Expectation of Exchange Rate, 2003-07 ............................7

4. Number of Investor Accounts and Listed Securities on the Shanghai Stock

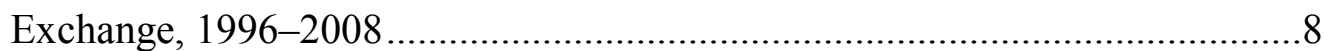

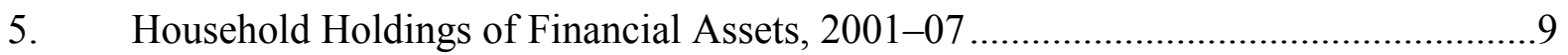

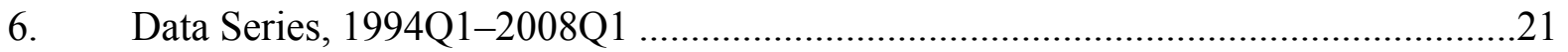

7. Actual and Fitted Values of the Money Demand Model ............................................23

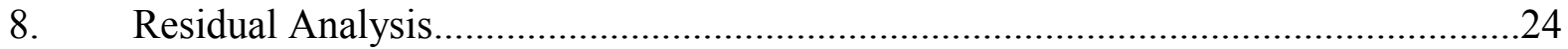

9. Recursive Least-Squares Parameter Constancy (recursive estimates).........................25

10. Recursive Least-Squares Parameter Constancy (t-values) .........................................26

11. Other Recursive Least-Squares Constancy Statistics .................................................2

12. Actual and Forecast Values of $\Delta(m-p)$.............................................................28

Tables

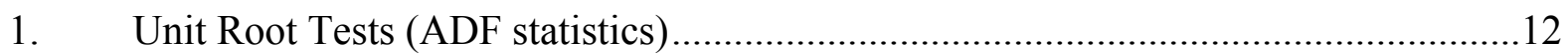

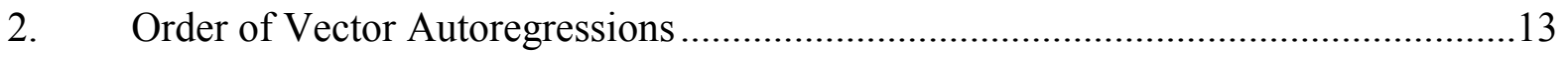

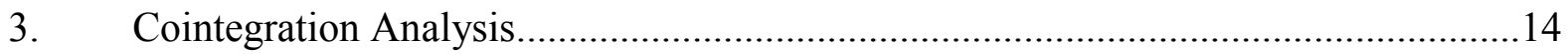

Appendices

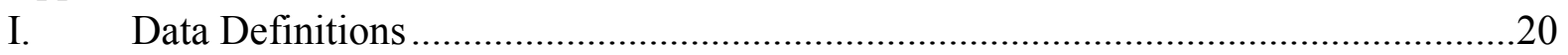

II. Unrestricted Error Correction Representation for Real Broad Money ........................22

III. Statistical Properties of the Dynamic Model of Money Demand ................................23

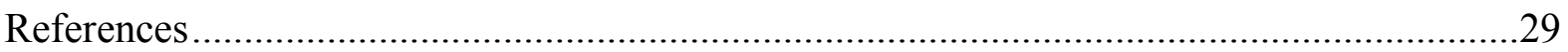




\section{INTRODUCTION}

Recent changes in China's financial system and the greater use of market-based signals for macroeconomic management pose challenges for the conduct of monetary policy. In particular, the gradual movement toward a more flexible exchange rate regime, ongoing interest rate liberalization, and the rapid development of capital markets have substantially changed the environment in which monetary policy operates. These changes may have a potentially large impact on the broad money demand, since they could raise the opportunity costs or provide some alternative assets for holding money. The latter phenomenon also might involve asset substitution between domestic and foreign currencies, as well as between monetary and nonmonetary assets.

The question of whether the money demand function is "stable" is one of the most important recurring issues in the theory and application of macroeconomic policy. What is being sought in a stable demand function is a set of necessary conditions for money to exert a predictable influence on the economy so that the central bank's control of the money supply can be a useful instrument of economic policy (see Judd and Scadding (1982)). Recent evidence suggests the money demand function in a number of highly industrialized and emerging market economies has become less stable.

Traditionally, the People's Bank of China (PBC), the country's central bank, has set an annual target for broad money (M2) growth. ${ }^{2}$ In doing so, a money demand function was estimated that included annual projected growth in gross domestic product (GDP) and changes in consumer prices. Most of the time, however, M2 growth in China exceeded the annual target (Figure 1). Part of the problem with these estimates may be measurement issues. Song (2007), for example, argues that the current measure of M2 in China may understate true money holdings, mainly because some deposit-like liabilities of deposittaking institutions are excluded. In addition, these estimates may fail to capture the impact of ongoing rapid development of China's capital markets (see Liang (2007)). Therefore, a broader estimate of money demand could improve the establishment of monetary targets and forecasting of aggregate demand.

\footnotetext{
${ }^{2}$ However, in 2008, the PBC did not announce an annual target for M2, as it typically does at its annual working conference.
} 


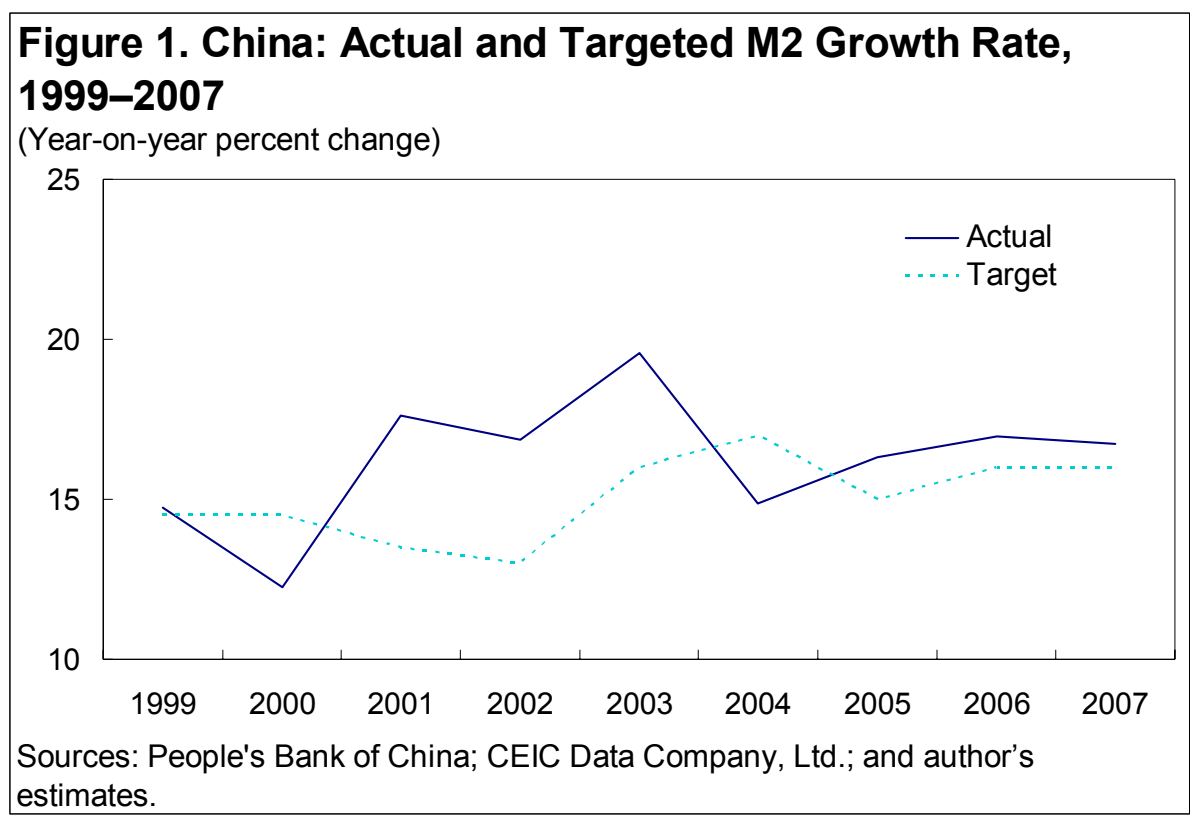

This paper uses an error correction model (ECM) to examine the empirical relationship between broad money and a range of macroeconomic and financial determinants in China. Focus is on the constancy of this relationship, especially in light of recent changes in the financial system. The paper is organized as follows: Section II briefly describes recent financial developments; Section III presents estimation results for a single-equation ECM of money demand using general-to-specific modeling; and Section IV summarizes the main conclusions.

\section{RECENT DEVELOPMENTS}

Since China initiated the process of reform and opening up in the late 1970s, real GDP growth has averaged 9 percent a year, turning its economy into an important engine of global growth. In undertaking economic reform, China has adopted a gradual and orderly approach with an emphasis on stability, reflecting time needed to improve the breadth and quality of market infrastructure, including the legal and regulatory framework, accounting standards, professional expertise, and institutional capacity overseeing the financial sector. Among recent important changes to the financial system that might exert a major influence on money demand are interest rate liberalization, exchange rate reform, and capital markets development.

\section{Interest rate liberalization}

The overall reform strategy was set early on in the reform process - interest rates in the money and bond markets were liberalized first, followed by a gradual liberalization of interest rates on loans and deposits. For lending and deposit rates, reform measures were introduced on foreign currencies ahead of the domestic currency, on loans ahead of deposits, 
and on long-term and large-value loans and deposits ahead of short-term and small-value instruments (see $\mathrm{Hu}$ (2007)).

Since 1996, the interbank market rate, the bond market rate, and the issuing rate on government bonds and policy financial bonds have been liberalized; ${ }^{3}$ interest rates on foreign currency loans and large-value foreign currency deposits have been deregulated; and the floating band around the renminbi (RMB) lending rate has been widened gradually. In 2004, China introduced a floating central bank lending rate system and removed the ceiling on lending rates and floor on deposit rates of commercial banks. However, floor lending and ceiling deposit rates still exist. The Shanghai Interbank Offered Rate (SHIBOR), which was formally launched in January 2007, has since become the benchmark rate in the money market.

\section{Reform of the exchange rate regime}

Exchange rate reform has also moved ahead in recent years, with the foreign exchange market playing a larger role in establishing the renminbi (RMB) exchange rate. On July 21, 2005, the PBC announced that it would adopt a market-based managed floating exchange rate regime with reference to a basket of currencies, which has led to greater RMB flexibility. During the period July 2005-March 2008, the RMB appreciated by nearly 18 percent against the U.S. dollar and in real effective terms by around 14 percent (Figure 2). ${ }^{4}$

A number of other reforms have been initiated to give the market a bigger role in determining the RMB exchange rate. These measures include introducing a market-maker system and over-the-counter transactions in the interbank foreign exchange market; introducing forward and swap transactions; and widening the daily floating band of the RMB against the U.S. dollar in the interbank spot foreign exchange market.

\footnotetext{
${ }^{3}$ Policy financial bonds are issued by the large state policy banks and traded on the interbank market.

${ }^{4}$ Sources: PBC; and IMF, International Financial Statistics.
} 

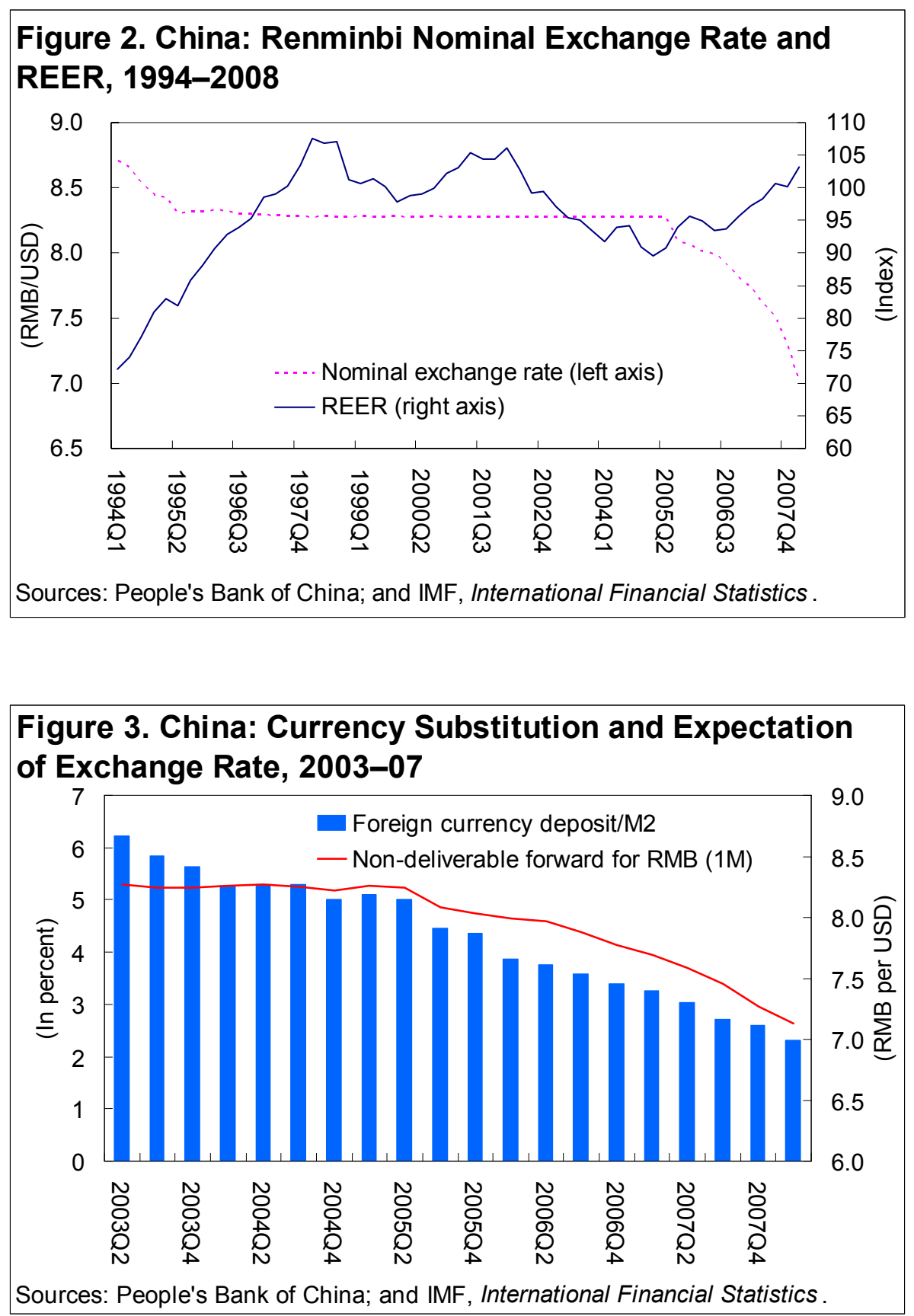

Inevitably, these changes have raised expectations of a further RMB appreciation, which may be affecting the currency composition of deposits and resulting in a greater willingness to hold RMB balances (Figure 3). Since M2 statistics in China still do not include foreign currencies, the ongoing currency substitution would probably affect the size of M2.

Commonly, the inclusion of the exchange rate in the money demand function can be justified by the fact that changes in the exchange rate alter the domestic value of foreign assets and therefore affect wealth. In addition, expected exchange rate changes can be seen as indicative 
of expected return on foreign monetary assets and therefore could influence the opportunity cost of holding domestic monetary assets (see Hanburger (1977)). ${ }^{5}$

- Development of capital markets. Since the Shanghai Stock Exchange was established in 1990 and households were allowed to open mutual funds accounts in 1991, capital markets have developed rapidly in China (Figures 4 and 5). From 1993 to 1998, China consolidated its capital markets and associated regulations, with the establishment of China Securities Regulatory Commission (CSRC) during this period as a key milestone. From 1998 onward, with the promulgation of the Securities Law, the legal status of China's capital markets in the economy was formalized and strengthened, with a series of major reforms implemented to facilitate further development. These measures included the initiation of nontradable share reform, restructuring of securities companies, improvement in share issuance procedures, and promotion of institutional investors. By end-2007, stock issues of listed companies totaled US\$204 billion and bond issues totaled US\$124 billion (of which US\$7.5 billion were from convertible bond issues). ${ }^{6}$

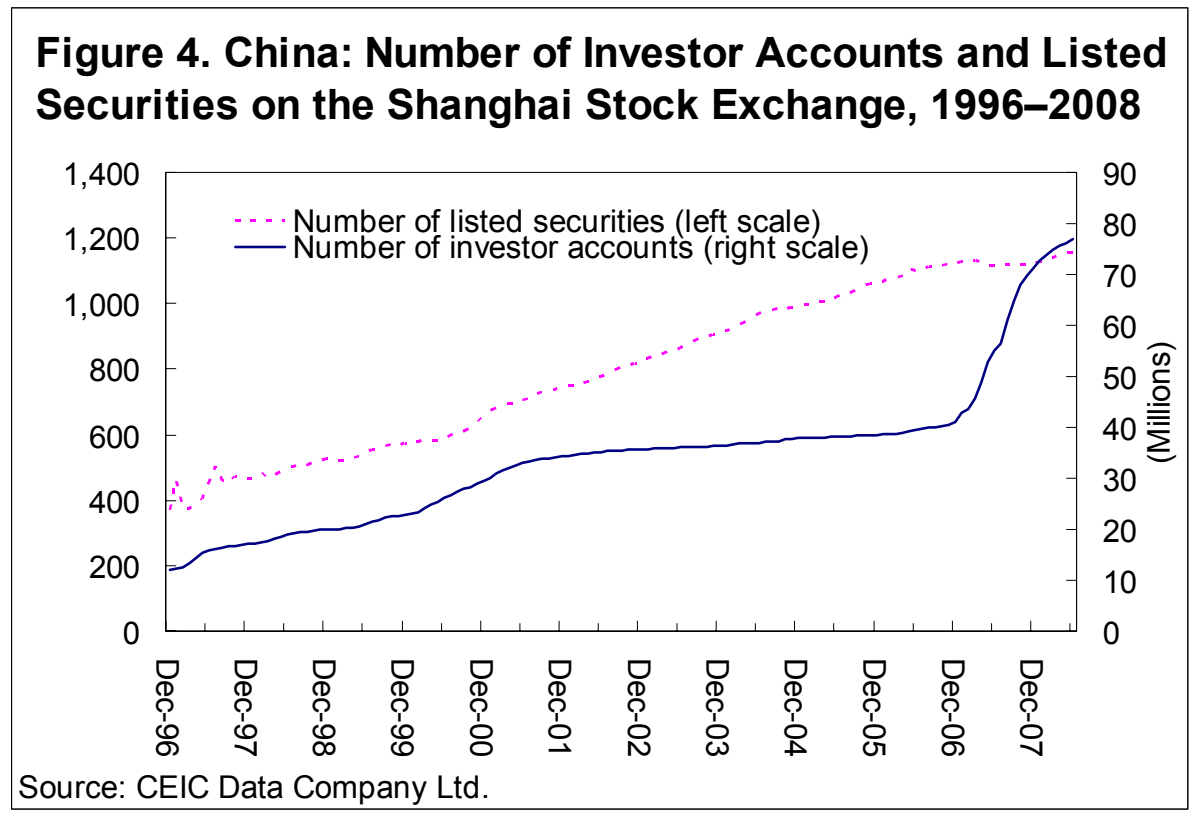

\footnotetext{
${ }^{5}$ In Japan, for example, the instability in money demand appears to be associated with a strong devaluation of foreign assets denominated in yen after the Plaza Accord of 1985 (see Yamada (2000)). If one includes the exchange rate in the model, it is possible to find cointegration between real money, income, interest rate, and exchange rate (see Bahmani-Oskooee and Shabsigh (1996); and Yamada (2000)).

${ }^{6}$ Source: CRSC (2008).
} 


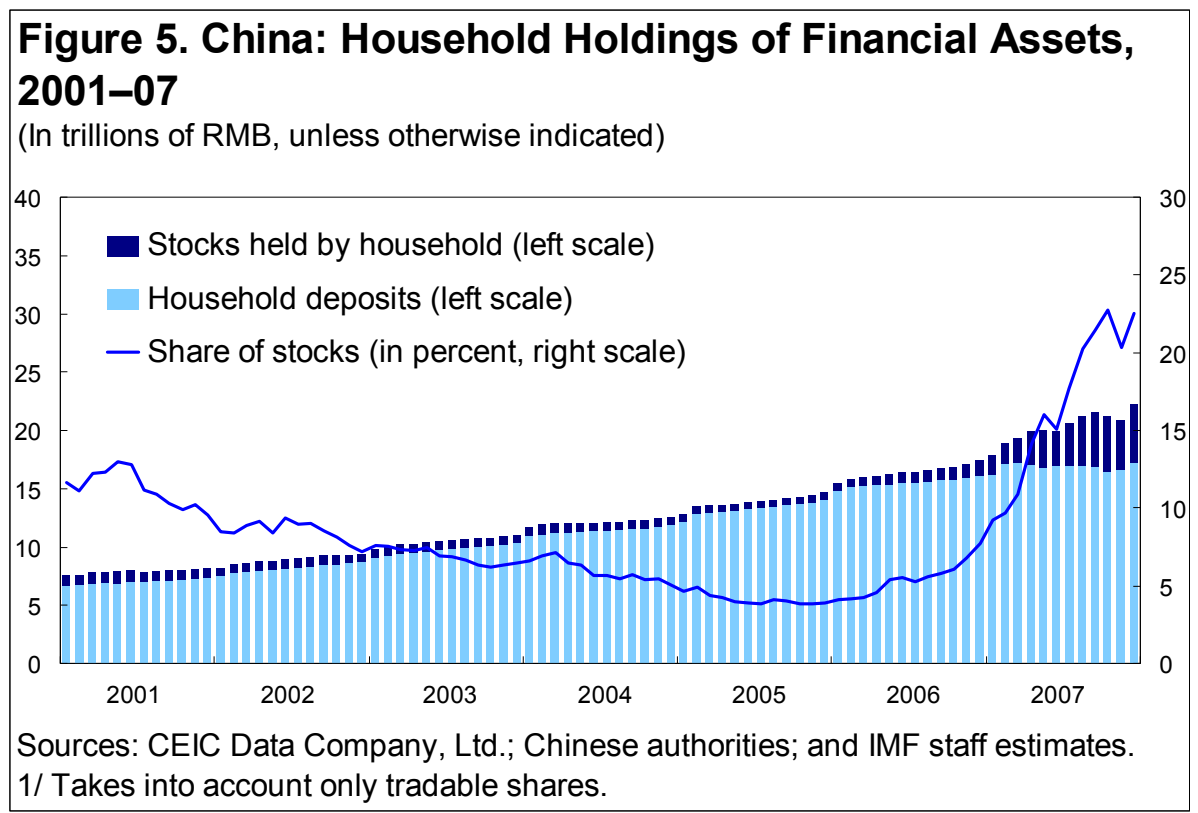

The capital markets offer a diversified investment channel for Chinese households and firms, which have likely altered factors influencing their money holdings. With the emergence and growth of capital markets, the range of investment products has expanded as expected. In addition, the means by which household wealth is managed is evolving rapidly. Wealth management services are proliferating, with the number of individual investor accounts increasing from fewer than 9 million in 1992 to nearly 138 million at end-2007.

\section{A Model of Money Demand In China}

This section presents estimation results for a single-equation ECM of money demand using general-to-specific modeling. First, some earlier studies on China's money demand are reviewed. Second, integration and cointegration tests are run on a number of variables, and cointegration restrictions and the adjustment mechanism are examined within the Johansen framework. Third, in light of the cointegration results and weak exogeneity using Johansen's procedure, a parsimonious, conditional, single-equation ECM model for money demand is developed.

\section{A. Earlier Studies}

A number of previous studies have analyzed monetary conditions in China. They can be categorized into two distinct modeling approaches (see Austin et al., (2007)), although most of these studies focus on the period before major economic reforms noted in the previous section were undertaken. Beginning with Chow (1987), the first approach applies conventional models developed to estimate money demand in advanced economies (in addition, see Chen (1997); Deng and Liu (1999); Hafer and Kutan (1993 and 1994); Huang (1994); and Yu and Tsui (2000)). In contrast, the second approach has adapted these frameworks to the specific conditions of the Chinese economy (see Feltenstein and 
Farhadian (1987), Feltenstein and Ha (1992), Girardin (1996), Ma (1993), Qin (1994), and Yi (1993)). Models have typically included extra variables to factor in different aspects of the transition process. For example, much of the work involving Feltenstein uses a constructed "true" price level owing to the inability of measured prices to reflect market conditions with partial price controls in effect. Yi (1993) adds monetization and inflation expectation variables into the money demand function, which enhanced significantly its explanatory power. Qin (1994) introduces two more factors in his money demand equation: (i) the ratio of the growth rates of total savings and loans to capture the special feature of a centrally planned economy; and (ii) a monetization index to approximate the transitional feature of China's economic reforms, whereas Girardin (1996) uses differences in size of state and nonstate industrial sectors to proxy institutional change.

These studies underscore several major points relevant to modeling and estimating the demand for money - mainly the choice of relevant variables and specification of the estimated model. Failure to provide due consideration to these issues has tended to yield poor results (see Sriram (2001)). For the former, proper specification of opportunity cost variables has been shown in other studies to be the most important factor in getting meaningful results. Regarding the latter, ECMs have been shown to perform well in providing a dynamic framework for estimating short- and long-run properties of money demand. In this paper, recent developments in computer-automated model selection help obtain a parsimonious, empirically constant, data-coherent ECM for broad money demand in China.

\section{B. Model Specification}

In a modern economy, money is conventionally held for at least two reasons: (i) as a means of smoothing differences between income and expenditure streams, and (ii) as one among several assets in a portfolio (see Ericsson and Sharma (1996)). The standard theory of money demand posits:

$$
M / P=f(Y, \mathbf{R})
$$

where $M$ is nominal money demand, $\mathrm{P}$ is the price level, $\mathrm{Y}$ is a scale variable for income or output, and $\mathbf{R}$ is a vector (in bold) of returns on various assets. The function $f$ is increasing in $\mathrm{Y}$, decreasing in those elements of $\mathbf{R}$ associated with assets excluded from $M$, and increasing in those elements of $\mathbf{R}$ for assets included in $M$. Commonly, (1) is also specified in loglinear form, albeit with the interest rates as levels.

In light of China's financial structure and data described later in this section, four assets are considered here: broad money, domestic goods, equity shares, and foreign currency. ${ }^{7}$ The

\footnotetext{
${ }^{7}$ Various capital controls are still in place in China, limiting holdings of nonmonetary foreign assets. Thus, they are excluded here.
} 
nominal returns for the first three are denoted $R^{d}, \Delta p, \Delta s$, respectively. For foreign currency, the nominal return and change in the exchange rate are denoted $R^{f}$ and $\Delta e$, respectively (see Appendix I for a complete description of these data). Thus, (1) can be written as follows (logs are in lower case):

$$
m-p=\mu_{0}+\mu_{1} y+\mu_{2} R^{d}+\mu_{3} R^{f}+\mu_{4} \Delta p+\mu_{5} \Delta s+\mu_{6} \Delta e .
$$

The coefficient $\mu_{0}$ is an intercept, $\mu_{1}$ the income elasticity, and $\mu_{2} \ldots \mu_{6}$ the semi-elasticities on the RMB deposit interest rate, foreign currency deposit interest rate, inflation rate, change of stock prices, and change in the exchange rate, with expected signs on the coefficients $\mu_{1}>0, \mu_{2}>0, \mu_{3}<0, \mu_{4}<0, \mu_{5}<0, \mu_{6}<0$.

\section{Integration and Cointegration Tests}

Initially, unit root tests are conducted on each right-hand side variable in equation (2). Subsequently, Johansen's maximum likelihood procedure is applied to test for cointegration among real money, real output, the RMB deposit rate, the U.S. dollar deposit rate, stock prices, the inflation rate, and the exchange rate. Using this framework, coefficient restrictions and the adjustment mechanisms are examined (see Ericsson et al. (1996, 1998, and 2007)).

\section{Integration}

Table 1 shows Augmented Dickey-Fuller (ADF) statistics for the main variables in our analysis. Using standard unit root tests, all variables appear to be integrated in either the first or second order, with $m-p, R^{d}, R^{f}, \Delta p, \Delta e$, and $\Delta s$ as I(1) and $p, e, s$ as I(2). For $y$, the statistical evidence is less conclusive. The estimated root for $\Delta y$, however, is $0.19(=1-0.81)$, which is much less than unity, suggesting that $y$ is in fact $\mathrm{I}(1)$. 
Table 1. China: Unit Root Tests (ADF statistics) $)^{1,2,3}$

\begin{tabular}{ccccccccccc}
\hline & \multicolumn{10}{c}{ Variable } \\
\cline { 2 - 11 } Null Order & $m-p$ & $y$ & $R^{d}$ & $R^{f}$ & $p$ & $e$ & $s$ & $\Delta p$ & $\Delta e$ & $\Delta s$ \\
\cline { 2 - 11 } $\mathrm{I}(1)$ & -0.70 & -0.32 & -0.41 & -1.07 & -0.82 & 3.45 & -3.17 & -3.33 & 1.64 & -3.29 \\
& $(-0.05)$ & $(-0.01)$ & $(-0.01)$ & $(-0.06)$ & $(-0.03)$ & $(0.24)$ & $(-0.26)$ & $(-0.41)$ & $(0.34)$ & $(-0.91)$ \\
$\mathrm{I}(2)$ & $-3.61^{*}$ & -2.68 & $-5.59^{* *}$ & $-6.42^{* *}$ & -3.33 & 1.64 & -3.29 & $-6.49^{* *}$ & $-12.66^{* *}$ & $-9.72^{* *}$ \\
& $(-1.00)$ & $(-0.81)$ & $(-1.07)$ & $(-0.87)$ & $(-0.41)$ & $(0.34)$ & $(-0.91)$ & $(-2.50)$ & $(-1.55)$ & $(-2.39)$ \\
$\mathrm{I}(3)$ & -3.15 & $-7.94^{* *}$ & $-6.79^{* *}$ & $-5.58^{* *}$ & $-6.49^{* *}$ & $-12.66^{* *}$ & $-9.72^{* *}$ & $-9.49^{* *}$ & $-5.87^{* *}$ & $-8.97^{* *}$ \\
& $(-2.35)$ & $(-4.09)$ & $(-4.23)$ & $(-2.43)$ & $(-2.50)$ & $(-1.55)$ & $(-2.39)$ & $(-5.70)$ & $(-4.80)$ & $(-3.94)$ \\
\hline
\end{tabular}

${ }^{1}$ The deviation from unity of the estimated largest root is in parentheses. It should be approximately zero if the series has a unit root.

${ }^{2}$ The lag length of the reported ADF regression is based on minimizing the Akaike Information Criterion, starting with a maximum of four lags.

${ }^{3}$ Here and elsewhere in this paper, asterisks ${ }^{*}$ and ${ }^{* *}$ denote rejection of the null hypothesis at the 5 percent and 1 percent critical values, respectively.

\section{Cointegration}

Cointegration analysis helps clarify the long-run relationships between integrated variables. Johansen's (1991) procedure is maximum likelihood for a finite-order vector autoregression (VAR), which is easily calculated for such systems and used here. Based on the data's statistical properties and the economic and historical context discussed in earlier sections, tests for cointegration are conducted among the I(1) variables, or $m-p, y, R^{d}, R^{f}, \Delta s$, $\Delta p$, and $\Delta e$.

Empirically, the lag order of the VAR is not known a priori, so testing for this may be fruitful to ensure reasonable power of the Johansen procedure. Beginning with a fourth-order VAR for $m-p, y, R^{d}, R^{f}, \Delta s, \Delta p$, and $\Delta e$ and including an intercept and seasonal dummies, it is statistically acceptable to simplify to a first-order VAR (see Table 2). 
Table 2. China: Order of Vector Autoregressions ${ }^{1}$

\begin{tabular}{cccc}
\hline & Null hypothesis & & \\
\hline System & $\mathrm{k}$ & 1444.0 & SC \\
\hline $\operatorname{VAR}(4)$ & 224 & & -38.52 \\
$\downarrow$ & & 1372.3 & -39.48 \\
$\operatorname{VAR}(3)$ & 175 & 1302.80 & -40.53 \\
$\downarrow$ & 126 & & -42.85 \\
$\operatorname{VAR}(2)$ & & 1266.25 & \\
$\downarrow$ & 77 & & \\
VAR(1) & 7 & & \\
\hline
\end{tabular}

${ }^{1}$ For each order of vector autoregressions, the number of unrestricted parameters $k$, the log-likelihood $£$, and the Schwarz criterion (SC) are reported. The SC in effect adjusts a measure of the model's goodness of fit (the log of the determinant of the estimated error covariance matrix) for the model's degree of parsimony. A smaller SC indicates a better-fitting model for a given number of parameters or a more parsimonious model for a given goodness of fit (see Ericsson and de Brouwer (1998)).

Standard estimates using Johansen's procedure are derived and applied to this first-order VAR (Table 3 ). The maximal eigenvalue and trace eigenvalue statistics $\left(\lambda_{\max }\right.$ and $\left.\lambda_{\text {trace }}\right)$ strongly reject the null hypothesis of no cointegration in favor of at least two cointegrating vectors. However, parallel statistics with a degree-of-freedom adjustment $\left(\lambda_{\max }^{a}\right.$ and $\left.\lambda_{\text {trace }}^{a}\right)$ suggest at least one cointegrating vector, and thus also likely indicate two cointegration relationships. 
Table 3. China: Cointegration Analysis

\begin{tabular}{|c|c|c|c|c|c|c|c|}
\hline Eigenvalues & 0.72 & 0.62 & 0.44 & 0.30 & 0.24 & 0.09 & 0.007 \\
\hline Hypotheses & $r=0$ & $r \leq 1$ & $r \leq 2$ & $r \leq 3$ & $r \leq 4$ & $r \leq 5$ & $r \leq 6$ \\
\hline$\lambda_{\max }$ & $66.85^{* *}$ & $50.93^{* *}$ & 29.74 & 18.42 & 14.50 & 5.14 & 0.37 \\
\hline$\lambda_{\max }^{a}$ & $57.85^{* *}$ & $44.07^{*}$ & 25.74 & 15.94 & 12.55 & 4.45 & 0.32 \\
\hline$\lambda_{\text {trace }}$ & 185.94 ** & 119.09 ** & 68.17 & 38.42 & 20.00 & 5.50 & 0.37 \\
\hline \multirow[t]{2}{*}{$\lambda_{\text {trace }}^{a}$} & $160.91^{* *}$ & 103.06 * & 58.99 & 33.25 & 17.31 & 4.76 & 0.32 \\
\hline & \multicolumn{7}{|c|}{ Standardized eigenvectors $\beta^{\prime}$} \\
\hline \multirow[t]{9}{*}{ Variable } & $m-p$ & $y$ & $R^{d}$ & $R^{f}$ & $\Delta s$ & $\Delta p$ & $\Delta e$ \\
\hline & 1.000 & -0.758 & -0.034 & 0.177 & -1.139 & 21.247 & 27.527 \\
\hline & -0.809 & 1.000 & -0.033 & -0.030 & 0.307 & 5.164 & -3.996 \\
\hline & -448.83 & 772.73 & 1.000 & -5.758 & 12.878 & -1035.2 & 2916.3 \\
\hline & 85.375 & -123.89 & 1.247 & 1.000 & -2.755 & 27.902 & -271.53 \\
\hline & 10.782 & -15.332 & 0.204 & 0.261 & 1.000 & -1.108 & 9.623 \\
\hline & -1.071 & 1.220 & -0.216 & 0.172 & 0.033 & 1.000 & 1.125 \\
\hline & 0.176 & -0.284 & 0.003 & -0.006 & 0.032 & 0.075 & 1.000 \\
\hline & \multicolumn{7}{|c|}{ Standardized adjustment coefficients $\alpha$} \\
\hline$m-p$ & -0.011 & 0.002 & 0.00005 & -0.002 & -0.011 & -0.002 & 0.033 \\
\hline$y$ & 0.006 & 0.0003 & 0.00002 & 0.001 & 0.0001 & -0.002 & 0.019 \\
\hline$R^{d}$ & 0.224 & 1.921 & 0.007 & 0.049 & -0.358 & 0.243 & 0.347 \\
\hline$R^{f}$ & -0.776 & 0.622 & 0.004 & 0.032 & -0.255 & -0.174 & -1.170 \\
\hline$\Delta s$ & 0.244 & -1.518 & -0.002 & 0.015 & -0.172 & -0.045 & -0.218 \\
\hline$\Delta p$ & -0.014 & -0.073 & 0.00009 & 0.001 & 0.004 & 0.002 & -0.003 \\
\hline \multirow[t]{3}{*}{$\Delta e$} & -0.014 & 0.003 & -0.0002 & 0.0003 & -0.005 & 0.0002 & -0.003 \\
\hline & \multicolumn{7}{|c|}{ Weak exogeneity test statistics } \\
\hline & $m-p$ & $y$ & $R^{d}$ & $R^{f}$ & $\Delta s$ & $\Delta p$ & $\Delta e$ \\
\hline \multirow[t]{3}{*}{$\chi^{2}(1)$} & 1.36 & 1.45 & 0.31 & $6.68^{\star *}$ & 1.56 & 2.28 & 8.02 ** \\
\hline & \multicolumn{7}{|c|}{ Statistics for testing the significance of a given variable } \\
\hline & $m-p$ & $y$ & $R^{d}$ & $R^{f}$ & $\Delta s$ & $\Delta p$ & $\Delta e$ \\
\hline \multirow[t]{3}{*}{$\chi^{2}(1)$} & 0.44 & 0.12 & 1.07 & 11.94 ** & $10.19^{\star *}$ & $10.95 * *$ & 11.54 ** \\
\hline & \multicolumn{7}{|c|}{ Multivariate statistics for testing stationarity } \\
\hline & $m-p$ & $y$ & $R^{d}$ & $R^{f}$ & $\Delta s$ & $\Delta p$ & $\Delta e$ \\
\hline$\chi^{2}(6)$ & 45.13 ** & $43.94^{\star *}$ & $56.94^{\star *}$ & $54.07^{* *}$ & $33.80^{* *}$ & 39.74 ** & $54.88^{* *}$ \\
\hline
\end{tabular}

Table 3 also reports the standardized eigenvectors and adjustment coefficients, denoted $\beta^{\prime}$ and $\alpha$, respectively. The first row of $\beta^{\prime}$ is the estimated cointegrating vector, which, from equation (2), can be written in the form of: 
$m-p=\hat{\mu}_{0}+0.758 y+0.034 R^{d}-0.177 R^{f}+1.139 \Delta s-5.312(4 \cdot \Delta p)-6.882(4 \cdot \Delta e)$,

where $\wedge^{\wedge}$ denotes the corresponding estimate. Each coefficient appears to have the expected sign except $\Delta s$. Inflation (measured as an annual rate) also has a high semi-elasticity. This could reflect the significant impact in China that the return on real assets may have on money demand (since the inflation rate could be regarded as a proxy for a return on real assets given past interest rate caps and price controls).

The adjustment coefficients $\alpha$ in Table 3 measure the feedback effects of the (lagged) disequilibrium in the cointegrating relation for variables in the VAR. Specifically, -0.011 is the estimated feedback coefficient for the money equation. The negative coefficient implies that lagged excess holdings of money induce smaller holdings of current money, with the small numerical value implying slow adjustment to remaining disequilibriumapproximately 1.1 percent in the first quarter. The size of the estimated coefficient lies at the lower end for developed and developing countries: $-0.26,-0.15$, and -0.20 where found for the Netherlands, Germany, and France, respectively, and -0.12 and -0.08 for Argentina and Greece (see Taylor (1986) and Ericsson and Sharma (1996)). The lower adjustment coefficient for China may reflect the lack of availability of alternative assets to M2 and a generally repressed financial system.

The remainder of Table 3 reports three types of statistics - one for testing the weak exogeneity of a given variable in the cointegrating vector, the second for the significance of a given variable in the cointegrating vector, and the third for the stationarity of a given variable. Each statistic tests the linear restrictions on $\alpha$ or $\beta$ by direct application of Johansen and Juselius (1990), and each is asymptotically chi-squared under the associated null hypothesis. In the first chi-squared test, $y, R^{d}, \Delta s$, and $\Delta p$ appear weakly exogenous when tested individually, but not $R^{f}$ and $\Delta e$. Confirmation of weak exogeneity permits analysis of the cointegrating vector in a single equation conditional ECM of money without loss of information, which is done in the next section. In the second chi-squared test, which looks at the significance of individual variables in the cointegrating vector, we see whether the corresponding coefficient in eigenvectors $\beta$ can be set to zero. $R^{f}, \Delta s, \Delta p$, and $\Delta e$ appear to be very significant, suggesting their importance in the VAR. The final chi-squared test on the stationarity of a given variable is reported in Table 3. Empirically, all the tests reject stationarity of these variables at a highly significant level. 


\section{A Dynamic Model of Money Demand}

This section estimates an autoregressive distributed lag (ADL) model and simplifies it to a parsimonious ECM. ${ }^{8}$ Given the choice of variables and the lag lengths in the VAR above, a fourth-order ADL appears a natural starting point for single equation modeling. This regression is modified in two ways. First, a dummy variable $D_{-} c r_{t}$ for 1997Q3-1998Q3 is included to account for fluctuations in money demand associated with the Asian financial crisis. Second, a dummy variable $D_{-} e x_{t}$ for 2005Q3-2008Q1 is added to reflect RMB exchange rate regime reform since 2005 , which is intended to capture one-way expectations of an RMB appreciation.

Most of the individual coefficients in the fourth-order ADL are estimated imprecisely and are of little interest by themselves. However, the long-run solution of the ADL shown in equation (4) is of greater relevance, as estimated coefficients are well determined,

$$
\begin{array}{rrrr}
m-p=1.239+0.615 y+0.081 R^{d}-0.141 R^{f}-0.006 \Delta s-34.884 \Delta p-4.589 \Delta e \\
(20.83) \quad(2.64) \quad(0.33) \quad(0.39) & (0.93)
\end{array}
$$

where $t=52$ [1995Q2-2008Q1], with standard errors shown in parentheses.

ADLs have error correction representations. Thus, the long-run money demand relation can be explicitly embedded in an ADL model and written as an ECM. Appendix II lists the estimated coefficients, standard errors, and test statistics for the ECM representation of the fourth-order ADL model of $m-p, y, R^{d}, R^{f}, \Delta s, \Delta p$, and $\Delta e-$ a starting point for the general-to-specific modeling. However, when the fourth-order ADL is transformed to its unrestricted ECM representation, many of the coefficients are both economically less relevant and statistically insignificant.

The general-to-specific process of streamlining an initial unrestricted model follows either a "liberal strategy," which minimizes the non-deletion probability of relevant variables to keep as many variables that might matter as possible, or a "conservative strategy," which minimizes the non-deletion probability of irrelevant variables to avoid retaining them. In this paper, we use the former strategy. PcGets provides a natural path for the simplification of the ADL to a highly parsimonious, economically interpretable, and statistically acceptable ECM

\footnotetext{
${ }^{8}$ The ECM is shown to contain information on both the short- and long-run properties of the money demand model, with disequilibrium as a process of adjustment to the long-run equilibrium. This has been done following the general-to-specific methodology as implemented in the PcGets software (see Hendry and Krolzig (2001)).
} 
in equation $(5):^{9}$

$$
\begin{aligned}
& \Delta(m-p)_{t}=0.404 \Delta y_{t-1}+0.401 \Delta y_{t-2}+0.352 \Delta y_{t-3}+0.008 \Delta R_{t-1}^{d}+0.005 \Delta R_{t-2}^{f} \\
& (S E) \\
& (0.145) \quad(0.123) \\
& -0.929 \Delta^{2} p_{t}+0.416 \Delta^{2} p_{t-1}+0.599 \Delta^{2} p_{t-1}+0.336 \Delta^{2} p_{t-3}-0.097(m-p)_{t-1} \\
& +0.072 y_{t-1}-0.008 R_{t-1}^{f}-1.089 \Delta p_{t-1}+0.024 D_{-} e x_{t}
\end{aligned}
$$

where $t=52$ [1995Q2-2008Q1] $\quad R^{2}=0.74 \quad \hat{\sigma}=0.795$

Durbin Watson statistics $=2.5 \quad$ AR: $F(4,34)=1.033$

ARCH: $F(4,30)=0.563$

Normality: $\chi^{2}(2)=5.872 \quad$ RESET $^{10}: \mathrm{F}(1,37)=0.154 \quad$ Hetero: $\mathrm{F}(27,10)=0.308$

Ordinary equation standard errors appear in parentheses.

\section{E. The Model's Properties}

This section considers the economic interpretation and statistical properties of the ECM in equation (5). In the first section, we consider the short- and long-run properties of the model. The second section discusses the model's statistical properties.

\section{Short- and long-run properties}

Both short- and long-run properties can be derived from equation (5). The coefficient on the error correction terms are highly significant statistically, establishing that a long-run (cointegrating) relationship exists between real money, real output, both RMB and foreign currency deposit interest rates, and inflation. The size of the coefficients suggests the adjustment to equilibrium via the error correction term is slow. Several variables are found to affect growth in real money demand. Foremost, the previous quarter's real GDP growth has a positive effect. However, the coefficients on RMB and foreign currency deposit rates are very small, suggesting money demand is less sensitive to changes in interest rates. Inflation and its different lags have a mixed impact on money demand, but with current inflation having a significantly negative effect. The changes in exchange rates do not enter our final

\footnotetext{
${ }^{9}$ PcGets selects a data-congruent model even though the precise formulation of econometric relationship among the variables of interest is not known a priori. Starting from a general model that is data congruent, PcGets eliminates statistically insignificant variables, with diagnostic tests checking the validity of these "reductions" to preserve the data congruency in the final specification.

${ }^{10}$ Regression Specification Error Test.
} 
model, but greater exchange rate flexibility since 2005 (through the dummy variable $D_{-} e x_{t}$ ) seems to induce more money demand, as expected. In addition, changes in stock prices $\left(\Delta s_{t-i}\right)$ and Asian financial crisis $\left(D_{-} c r_{t}\right)$ are statistically insignificant in the model.

Taking (5), the long-run static money demand function is: ${ }^{11}$

$$
(m-p)^{s}=0.742 y-0.082 R^{f}-2.81(4 \cdot \Delta p)
$$

The signs of the coefficients in equation (6) satisfy those typically found in a money demand equation. In such a steady state, real money demand depends positively on the output and negatively on foreign deposit interest rate and the inflation rate. Interestingly, it is the U.S. dollar rather than the RMB interest rate that enters the long-run function, although the coefficient is very small. The fact that ceilings still exist on RMB deposit rates may mean they play a less effective role in terms of influencing money holdings.

Other steady-state solutions can also be derived. For example, if money and output are assumed to grow at the same rate $(\Delta(m-p)=\Delta y \equiv \mathrm{g})$, the dynamic equilibrium solution is:

$$
(m-p)^{d}=0.742 y-0.082 R^{f}-2.81(4 \cdot \Delta p)-1.778(4 \cdot g)
$$

where ( $4 \cdot g$ ) is the annualized GDP growth rate. Equations (3), (4), and (6), and equally (7), present estimates of the long-run money demand relation under somewhat different assumptions. Equation (3) does not assume weak exogeneity, but (4) and (6) do, with the latter also reflecting a valid simplification from Table 3. The estimates of the long-run solution in equation (6) from ECM are also numerically close to the system estimates of cointegrating vector in equation (3), as are the single-equation estimates in equation (4) from the unrestricted ADL.

\section{Statistical properties of the model}

In order to test the influence of major changes to the financial system on money demand, we further examine the statistical properties of equation (5). Results are presented in Appendix III, including actual and fitted values and residual and recursive analyses. In addition, we assess the constancy of the model using ex post forecasts. From this, we find that the estimated model of money demand seems to have sensible statistical properties over

\footnotetext{
${ }^{11}$ Assuming $\Delta(m-p)=\Delta y=\Delta R=\Delta^{2} p \equiv 0$ in (5); time subscripts are dropped, and the dummy can be ignored.
} 
the period 1994Q1-2008Q1, suggesting its empirical constancy holds in the face of interest rate liberalization, exchange rate reforms, and capital market development.

\section{Conclusion}

Despite the recent changes in China's financial system, this paper confirms that a stable broad money demand function exists when taking proper account of asset substitution and using appropriate econometric techniques. Strong evidence is found supporting the hypothesis of a stable long-run relationship between real money and real GDP, with an estimated income elasticity of less than unity. Current inflation has a significantly negative impact on the money demand. However, the impact of RMB and foreign deposit interest rates on money demand are relatively small, which may reflect the fact that some caps on deposit rates still exist. Expectations of an RMB appreciation since 2005 appear to induce slightly more money demand in our model. However, stock prices do not enter our short- and long-run models. reflecting the underdevelopment nature of the capital markets and strong incentives to hold money for the cautionary purposes during the economic and social transition in China.

Even so, the fundamental changes currently underway in China's financial system are likely to alter the structure of the money demand function and, as a consequence, further complicate the conduct of the monetary policy. With further interest rate liberalization, movement to a more flexible exchange rate regime, and development of capital markets, factors influencing money demand are likely to change over time. The greater availability of alternative assets, either domestic or overseas - in the latter case through ongoing liberalization of capital flows, and efficiency gains in the financial system could have a positive effect on money demand. Better understanding of the nature and trend of the money demand will be key to formulating and implementing monetary policy successfully under a proper policy framework. 


\section{Appendix I: Data Definitions}

This section describes the data used and their basic properties. ${ }^{12}$ The data series used are shown in the table below. Quarterly data are compiled for the period 1994Q1-2008Q1. The series are not seasonally adjusted because such pre-filtering may affect short-term dynamics. Rather, seasonality is captured explicitly in estimating the model by including seasonal dummies in the set of regressors.

\begin{tabular}{|c|c|c|c|}
\hline Series Name & Series Description & Unit of Series & Source \\
\hline Money aggregate (M) & Money supply M2, nominal & RMB, billions & CEIC \\
\hline Price $(P)$ & Consumer price index, end-of-period & Index & WEO (IMF) \\
\hline Real output (Y) & GDP at constant prices & RMB, billions & WEO (IMF) \\
\hline $\begin{array}{l}\text { RMB deposit interest rate } \\
\left(R^{d}\right)\end{array}$ & $\begin{array}{l}\text { One-year household saving rate for RMB, net of } \\
\text { withholding interest tax }{ }^{13}\end{array}$ & Percent & IFS \\
\hline $\begin{array}{l}\text { USD deposit interest rate } \\
\left(R^{f}\right)\end{array}$ & $\begin{array}{l}\text { One-year time deposit rate for USD, net of } \\
\text { withholding interest tax }\end{array}$ & Percent & $\begin{array}{l}\text { IFS (IMF); PBC; } \\
\text { Bank of China. }\end{array}$ \\
\hline Stock prices $(S)$ & Shanghai Stock Exchange Composite Index & Index & CEIC \\
\hline Exchange rate $(E)$ & Nominal exchange rate & RMB per USD & IFS (IMF) \\
\hline
\end{tabular}

Notes: CEIC: CEIC Data Company Ltd.; WEO: IMF, World Economic Outlook Database; IFS: IMF, International Financial Statistics Database.

Data are plotted to consider their properties for empirical modeling. In Figure 6, Panel (a) shows the logarithms of nominal money and prices $(m, p)$. Sharp increases in $p$ are visible during 1994-97 and 2004-08. Panel (b) plots the inflation rate and nominal money growth rate ( $\Delta p, \Delta m)$. Overall, these series move relatively closely. Panel (c) shows growth in real money and real GDP have coincided over the past decade. Panel (d) plots the real money growth rate and inflation $(\Delta(m-p), \Delta p)$, showing several periods, however, when the two variables appear to move in opposite directions, with both series also very volatile. Panel (e) shows the RMB and USD deposit rates $\left(R^{d}, R^{f}\right)$. Interestingly, these two series do not appear to move very closely with each other. Panel (f) plots the changes of exchange rate $(\Delta e)$ as well as changes in equity prices $(\Delta s)$. Even with significant the nominal appreciation of the RMB since 2005, little direct relationship appears to exist between the two variables.

\footnotetext{
${ }^{12}$ All empirical results in this paper were obtained using GiveWin 2.20, PcGive 10.3, and PcGets 1.02.

13 Interest earned on savings deposits was taxed at a rate of 20 percent effective November 1, 1999; this rate was decreased to 5 percent effective August 15, 2007.
} 
Figure 6. China: Data Series, 1994Q1-2008Q1
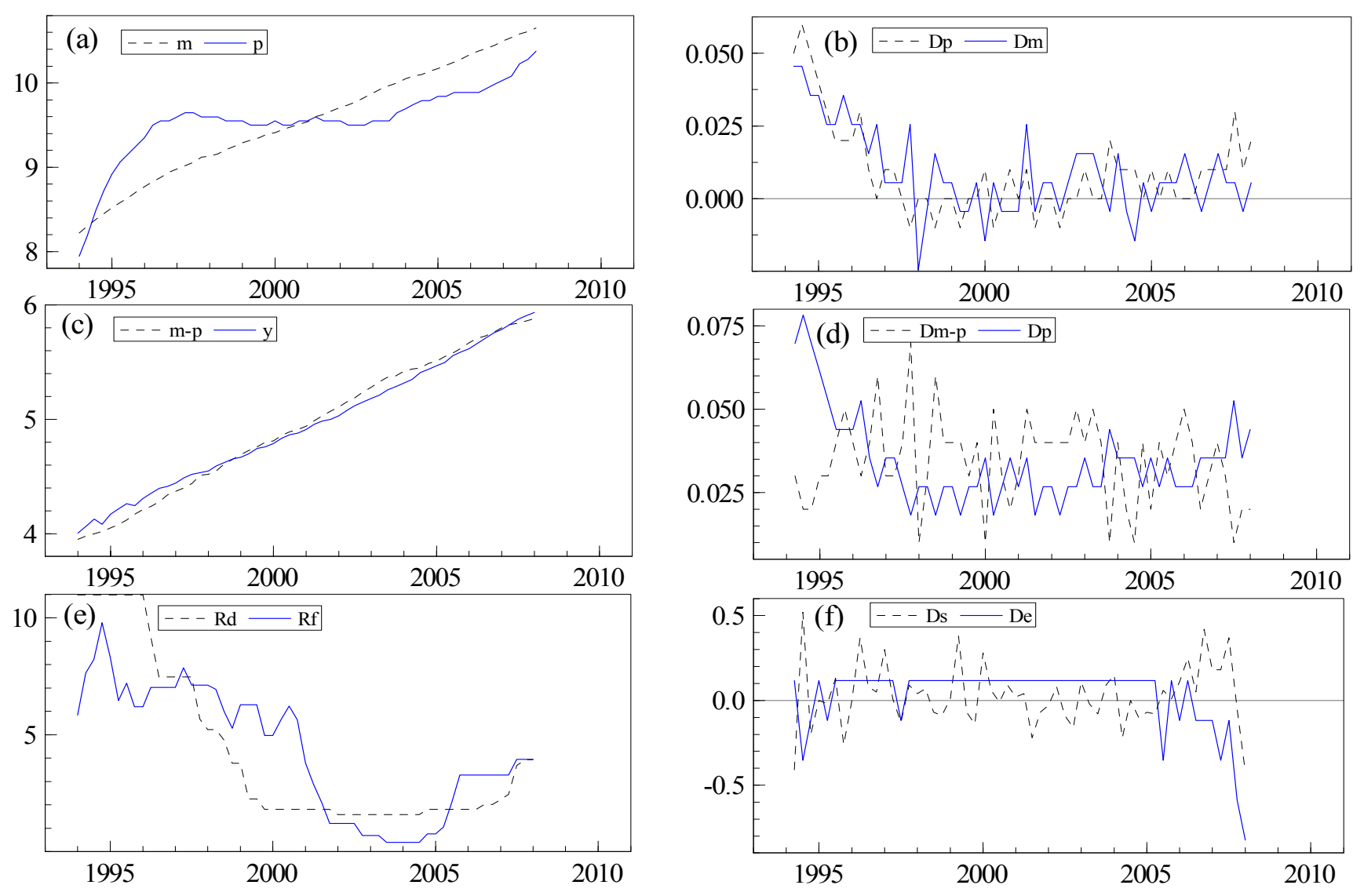
Appendix II: Unrestricted Error Correction Representation for Real Broad Money ${ }^{14}$

$\operatorname{Lag}(1)$

\begin{tabular}{|c|c|c|c|c|}
\hline Variable & 0 & 1 & 2 & 3 \\
\hline$\Delta(m-p)_{t-i}$ & $\begin{array}{c}-1.000 \\
(-)\end{array}$ & $\begin{array}{l}-0.451 \\
(0.323)\end{array}$ & $\begin{array}{l}-0.181 \\
(0.288)\end{array}$ & $\begin{array}{c}0.169 \\
(0.264)\end{array}$ \\
\hline$\Delta y_{t-i}$ & $\begin{array}{l}-0.330 \\
(0.708)\end{array}$ & $\begin{array}{c}0.440 \\
(0.516) \\
\end{array}$ & $\begin{array}{c}0.445 \\
(0.485) \\
\end{array}$ & $\begin{array}{c}0.337 \\
(0.365)\end{array}$ \\
\hline$\Delta R_{t-i}^{d}$ & $\begin{array}{c}0.002 \\
(0.006)\end{array}$ & $\begin{array}{c}0.006 \\
(0.006)\end{array}$ & $\begin{array}{c}0.002 \\
(0.006)\end{array}$ & $\begin{array}{c}0.004 \\
(0.005)\end{array}$ \\
\hline$\Delta R_{t-i}^{f}$ & $\begin{array}{l}-0.004 \\
(0.006)\end{array}$ & $\begin{array}{l}-0.012 \\
(0.008)\end{array}$ & $\begin{array}{c}0.009 \\
(0.007)\end{array}$ & $\begin{array}{c}0.001 \\
(0.006)\end{array}$ \\
\hline$\Delta^{2} S_{t-i}$ & $\begin{array}{c}0.014 \\
(0.023)\end{array}$ & $\begin{array}{c}0.016 \\
(0.049)\end{array}$ & $\begin{array}{c}0.023 \\
(0.038)\end{array}$ & $\begin{array}{c}0.008 \\
(0.026)\end{array}$ \\
\hline$\Delta^{2} e_{t-i}$ & $\begin{array}{c}0.147 \\
(0.529)\end{array}$ & $\begin{array}{c}0.036 \\
(1.321)\end{array}$ & $\begin{array}{l}-0.497 \\
(1.159)\end{array}$ & $\begin{array}{l}-0.106 \\
(0.697)\end{array}$ \\
\hline$\Delta^{2} p_{t-i}$ & $\begin{array}{l}-1.081 \\
(0.333)\end{array}$ & $\begin{array}{c}0.803 \\
(0.553)\end{array}$ & $\begin{array}{c}0.472 \\
(0.422)\end{array}$ & $\begin{array}{c}0.439 \\
(0.341)\end{array}$ \\
\hline$(m-p)_{t-i}$ & & $\begin{array}{l}-0.065 \\
(0.203)\end{array}$ & & \\
\hline$y_{t-i}$ & & $\begin{array}{c}0.040 \\
(0.296)\end{array}$ & & \\
\hline$R_{t-i}^{d}$ & & $\begin{array}{c}0.005 \\
(0.006)\end{array}$ & & \\
\hline$R_{t-i}^{f}$ & & $\begin{array}{l}-0.009 \\
(0.008)\end{array}$ & & \\
\hline$\Delta s_{t-i}$ & & $\begin{array}{l}-0.0004 \\
(0.061)\end{array}$ & & \\
\hline$\Delta e_{t-i}$ & & $\begin{array}{l}-0.302 \\
(1.236)\end{array}$ & & \\
\hline$\Delta p_{t-i}$ & & $\begin{array}{l}-2.296 \\
(0.898)\end{array}$ & & \\
\hline$D_{-} e x_{t}$ & $\begin{array}{c}0.021 \\
(0.017) \\
\end{array}$ & & & \\
\hline$D_{-} c r_{t}$ & $\begin{array}{l}-0.014 \\
(0.012)\end{array}$ & & & \\
\hline$S_{t i}$ & $\begin{array}{c}0.081 \\
(1.129)\end{array}$ & $\begin{array}{c}0.004 \\
(0.006)\end{array}$ & $\begin{array}{c}0.011 \\
(0.010)\end{array}$ & $\begin{array}{c}0.008 \\
(0.009)\end{array}$ \\
\hline
\end{tabular}

$\mathrm{T}=52$ [1995Q2-2008Q1], $\quad R^{2}=0.882, \quad \hat{\sigma}=0.947$

DW $=2.45, \quad$ AR: $\mathrm{F}(2,10)=1.301, \quad$ ARCH: $\mathrm{F}(2,8)=0.093$,

Normality: $\chi^{2}(2)=2.317, \quad$ RESET: $F(1,11)=0.263$

${ }^{14}$ The dependent variable is $\Delta(m-p)$. The variable $\left(S_{t i}\right)$ is a seasonal dummy, except $S_{t 0}$, which is the intercept term. 


\section{Appendix III: Statistical Properties of the Dynamic Model of Money Demand}

\section{Actual and Fitted Values}

Figure 7 provides a graphical analysis of the estimated equation(5). In Panels (a) and (b), the time-series and cross-sectional plots of the actual and fitted values for the whole sample are recorded; Panel (c) shows the residuals scaled by $\hat{\sigma}$, with values outside the \pm 2 band suggesting outliers. In Panel (d), the squared residuals also suggest major outliers. One possible explanation for outliers around 2001 could be due to revisions to monetary data in China. Starting in 2001, the PBC began incorporating clients' deposits in security companies into M2. In addition, since 2002, the PBC has made other revisions to monetary and financial data in line with the IMF's Monetary and Financial Statistics Manual (2000).

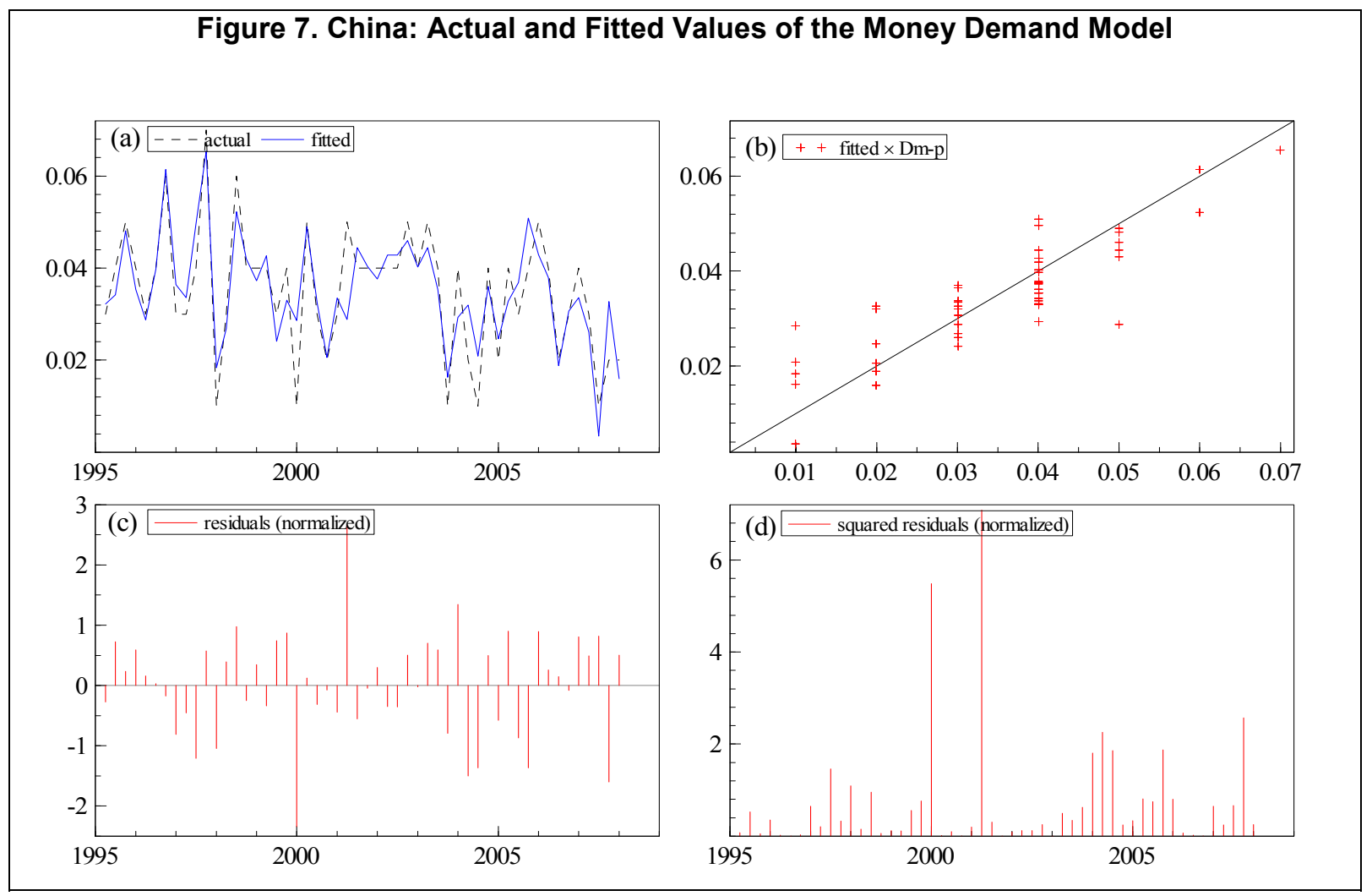

\section{Residual analysis}

Figure 8 provides further diagnostic information about the residuals. The correlelogram (Panel (a)) plots the autocorrelations (ACF) between successive lagged residuals, with the horizontal lines representing the approximate 95 percent confidence intervals. The partial correlelogram plots the partial autocorrelations (PACF). A white-noise residual would have most autocorrelations close to zero, which appears to be true here. 


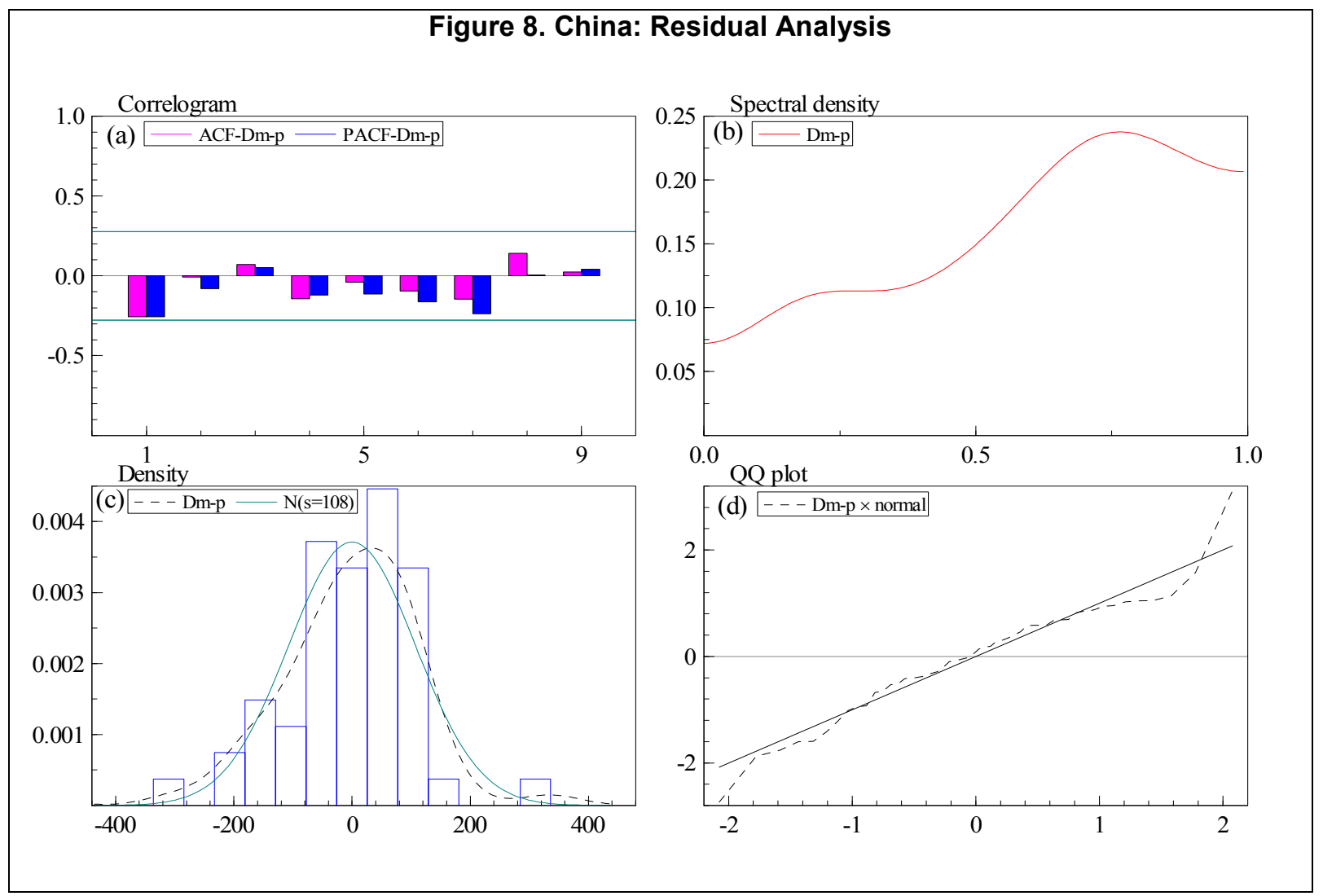

The spectral density (Panel (b)) is a weighted sum of the autocorrelations, which decomposes the series into components with different frequencies and amplitudes. In PcGets, it is symmetric around 0 and plotted over $[0, \pi]$ (the horizontal axis is scaled by $\pi$, reported as $[0,1])$. A white-noise series has a 'flat' spectrum, so we see residual autocorrelation is not apparent here.

The histogram (Panel (c)) is shown with a non-parametric interpolated density estimate and a matching normal distribution. Finally, the QQ plot (Panel (d)) shows the transformed cumulative distribution of the sample residuals, with the departure from the normal (straight) line in the upper tail consistent with the presence of outliers.

\section{Recursive analysis}

Parameter constancy is a critical issue for the money demand equation. Recursive least squares and the associated sequences of test statistics provide incisive tools for investigating constancy, with graphs used to summarize the large volume of output (see Hendry and Krolzig (2001)). 
Figure 9 shows the recursively estimated coefficients of variables in equation (5). Most coefficients appear constant, but significantly so only after $2002 .{ }^{15}$

Figure 9. China: Recursive Least-Squares Parameter Constancy (recursive estimates)
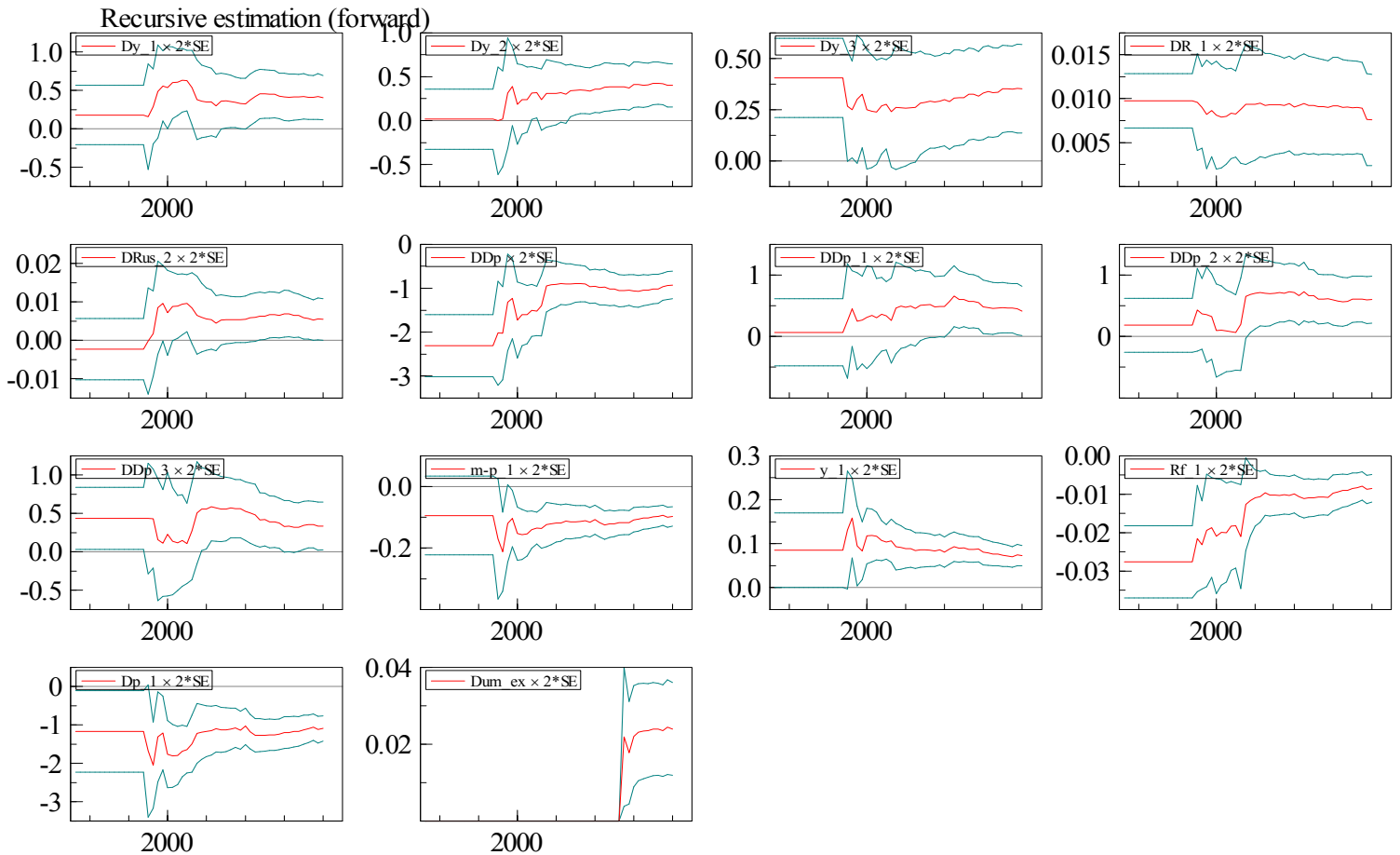

Figure 10 corroborates this by showing the t-values, almost all of which gradually diverge, as should occur with relevant regressors.

15 The "flat bands" up to $1998 \mathrm{Q} 3$ show the initialization period. 


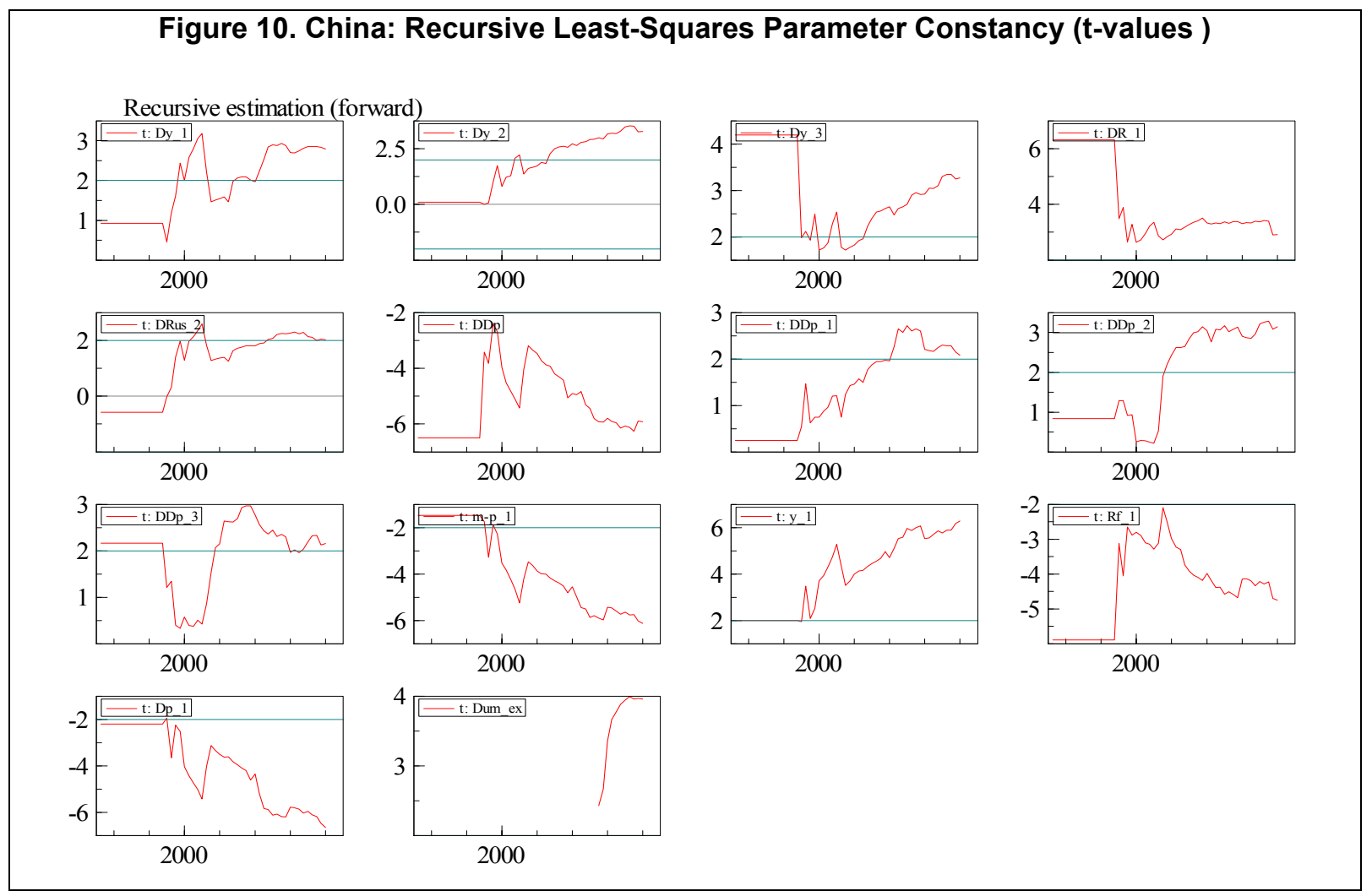

Finally, Figure 11 reports recursive least-squares (RLS) constancy statistics. Panel (a) shows the residual sum of squares (RSS) of each observation, and Panel (b) the one-step residuals, which are plotted with \pm 2 standard error bands. Any residual that lies outside of the error bands either are outliers or associated with changes in the standard error. The standard error increases around 2000, after which the bands are relatively constant. Panel (c) provides the break-point Chow test (where the forecast horizon is decreasing from left to right), and Panel (d) shows its probability value, with the 5 percent critical value shown as a straight line. 


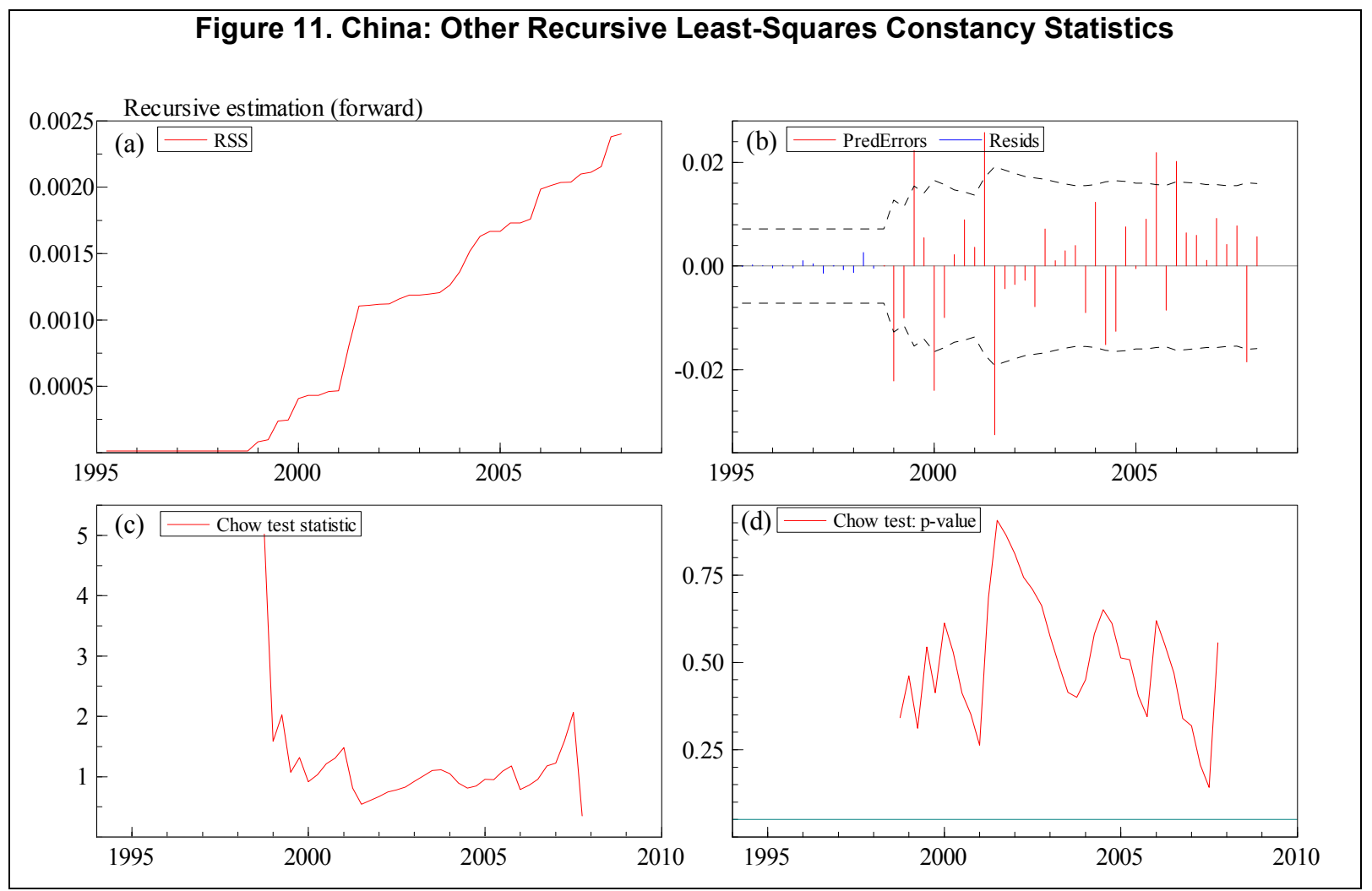

\section{(d) Analysis of forecasts}

Ex post forecasts can help assess the constancy of a model, so we consider such forecasts for equation (5). Thus we re-estimate (5) through 2006Q2 and use that estimated equation to forecast over the last two years. Figure 12 plots actual and forecast values of $\Delta(m-p)$, with the model tracking recent performance relatively well. 


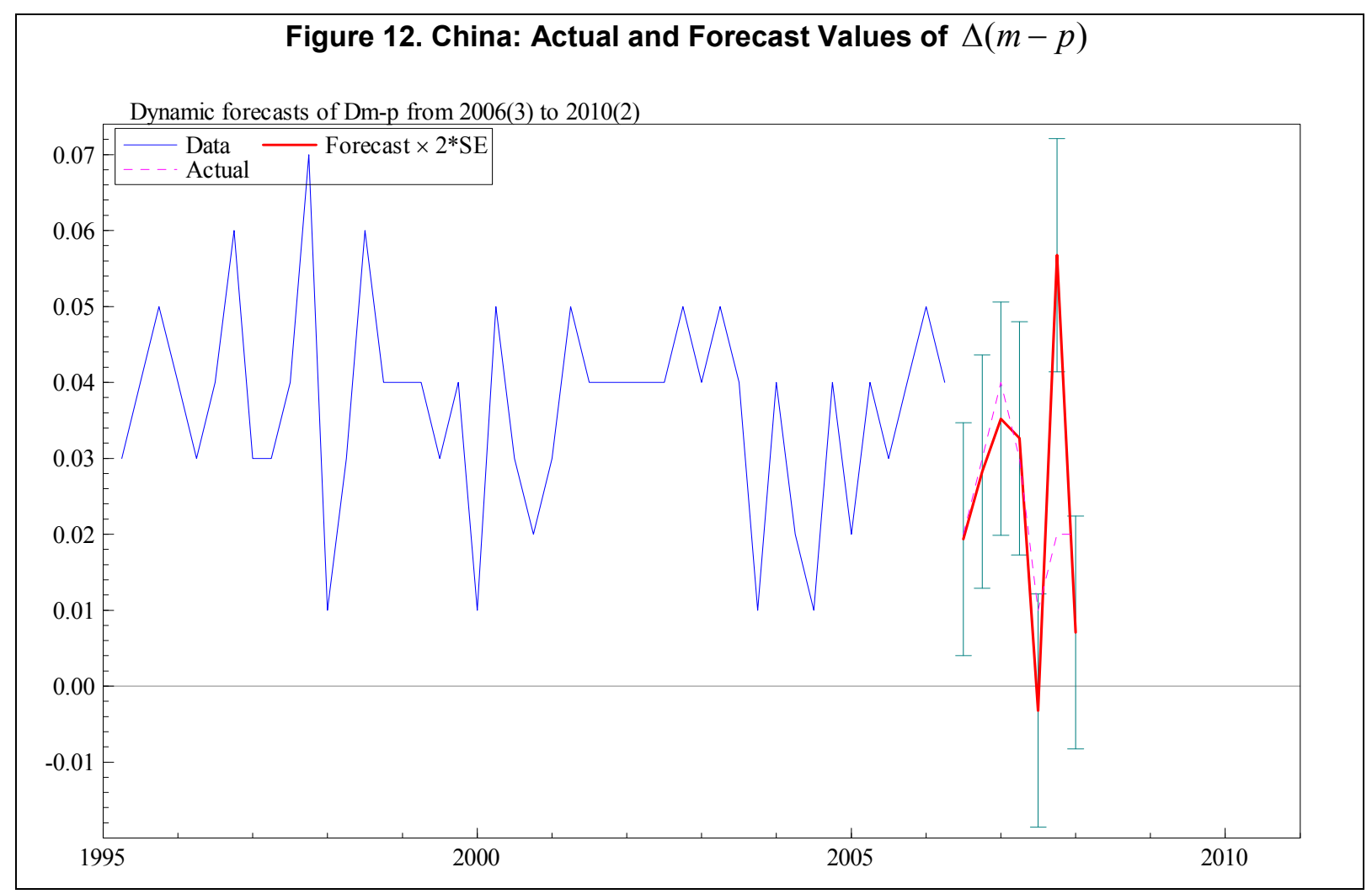




\section{REFERENCES}

Austin, Darran, Bert Ward, and Paul Dalziel, 2007, "The Demand for Money in China 19872004: A Non-linear Modeling Approach,” China Economic Review, Vol. 18, pp. 190-204.

Bahmani-Oskooee, Mohsen, and Ghiath Shabsigh, 1996, "The Demand for Money in Japan: Evidence from Cointegration Analysis," Japan and the World Economy, Vol. 8, pp.110.

Chen, Baizhu, 1997, “Long-Run Money Demand and Inflation in China," Journal of Macroeconomics, 19 (3), pp. 609-17.

Chow, Gregory C., 1987, "Money and Prices Level Determination in China," Journal of Comparative Economics, No. 11, pp. 319-33.

China Securities Regulatory Commission, 2008, China Capital Market Development Report 2007. Available via the internet: http://www.csrc.gov.cn

Deng, Shuhui and Bin Liu, 1999, "Modelling and Forecasting the Money Demand in China: Cointegration and Nonlinear Analysis," Annals of Operations Research, 87, pp.177-89.

Ericsson, Neil R., and Sunil Sharma, 1996, "Broad Money Demand and Financial Liberalization in Greece," International Finance Discussion Paper, No. 559, Board of Governors of the Federal Reserve System.

Ericsson, Neil R., and Gordon de Brouwer, 1998, "Modeling Inflation in Australia," Journal of Business and Economic Statistics, Vol. 14, No. 4 (October), pp.433-49.

Ericsson, Neil R., and Steven B. Kamin, 2007, "Constructive Data Mining: Modeling Argentine Broad Money Demand," prepared for a conference in honor of David F. Hendry, Oxford University, England (August).

Feltenstein, Andrew, and Ziba Farhadian-Lorie, 1987, "Fiscal Policy, Monetary Targets, and the Price Level in a Centrally Planned Economy: An Application to the Case of China," Journal of Money, Credit, and Banking, No.2, p. 137.

Feltenstein, A., and J. Ha, 1992, "The Link Between Macroeconomic Adjustment and Sectoral Output in Post-reform China," China Economic Review, No. 2, pp.109-124.

Girardin, Eric, 1996, "Is There a Long-Run Demand for Currency in China?” Economics of Planning No.3, pp. 169-84. 
Hafer, R.W., and A.M. Kutan, 1993, "Further Evidence on Money, Output, and Prices in China," Journal of Comparative Economics, No.3, pp. 701-09.

Hafer, R.W., and A.M. Kutan, 1994, "Economic Reforms and Long-Run Money Demand in China: Implications for Monetary Policy,” Southern Economic Journal, Vol. 60, pp. 936-945

Hendry, D. F., and Hans-Martin Krolzig, 2001, Automatic Econometric Model Selection Using PcGets 1.0 (London: Timberlake Consultants Ltd).

Hu, Xiaolian, 2007, “China's Approach to Reform," Finance and Development, Vol. 44 (Washington: International Monetary Fund).

Huang, Guobo, 1994, "Money Demand in China in the Reform Period: An Error Correction Model," Applied Economics, No.7, pp. 713-19.

Johansen, S., 1991, "Estimation and Hypothesis Testing of Cointegration Vectors in Gaussian Vector Autoregressive Models,” Econometrica, No.6, pp. 1551-80.

Johansen, Soren, 1992, “Testing Weak Exogeneity and the Order of Cointegration in U.K. Money Demand Data," Journal of Policy Modeling, No.14, pp. 313-34.

Johansen, Soren, and Katarina Juselius, 1990, "Maximum Likelihood Estimation and Inference on Cointegration - with Applications to the Demand for Money," Oxford Bulletin of Economics and Statistics, No.2, pp. 169-210.

Judd, John P. and John L. Scadding, 1982, “The Search for a Stable Money Demand Function: A Survey of the Post-1973 Literature," Journal of Economic Literature, Vol. XX, pp. 993-1023.

Liang, Hong and Eva Yi, 2007, "China: Why Should We Care about M3 Growth?” Asia Economics Flash, (July), Economic Research from the Gao Hua Portal.

Ma, Guonan, 1993, "Macroeconomic Disequilibrium, Structural Changes, and the Household Savings and Money Demand in China," Journal of Development Economics, No.1, pp. 115-36.

Organization for Economic Cooperation and Development, 2007, Economic Survey of the Euro Area. Available via the internet: http://www.oecd.org/eco/surveys/

Qin, Duo, 1994, "Money Demand in China: The Effect of Economic Reform," Journal of Asian Economics, Vol. 5, No.2, pp. 253-71. 
Sriram, Subramanian S., 2001, "A Survey of Recent Empirical Money Demand Studies," Staff Papers, International Monetary Fund, Vol. 47, No. 3, pp. 334-65.

Song, Guoqing, 2007, “Too Fast Money Supply Causes Inflation,” Presentation at China Economic Observer 10th Conference, CCER.

Taylor, M. P, 1986, "From the General to the Specific: The Demand for M2 in Three," Empirical Economics, Springer, Vol.11(4), pp. 243-61.

Yamada, H., 2000, "M2 Demand Relation and Effective Exchange Rate in Japan: A Cointegration Analysis," Applied Economics Letters, No.7, pp.229-32.

Yi, Gang, 1993, "Towards Estimating the Demand for Money in China," Economics of Planning, Vol. 26, pp. 243-70.

Yu, Qiao, and Albert.K. Tsui, 2000, "Monetary Services and Money Demand in China," China Economic Review, Vol. 2, pp. 134-148. 